This is an electronic version of an article published as: Arnott, J.T. \& Beese, W.J. (1997). Alternatives to clearcutting in BC coastal montane forests. The Forestry Chronicle, 73(6), 670-678.

The Forestry Chronicle is available online at: http://pubs.cif-ifc.org/journal/tfc and this article is available at: http://pubs.cif-ifc.org/doi/pdf/10.5558/tfc73670-6. 


\title{
Alternatives to clearcutting in BC Coastal Montane Forests
}

\author{
by J.T. Arnott ${ }^{1}$ and W.J. Beese ${ }^{2}$
}

The Montane Alternative Silvicultural Systems (MASS) partnership was formed in 1992 to test new approaches to harvesting high-elevation old-growth forests of Vancouver Island, British Columbia. Uniform Shelterwood (SW), Green Tree Retention (GT) and Patch Cuttings (PC) were tested as alternatives to Clearcutting (CC). All systems were compared to an Old Growth (OG) control. Harvesting was completed in 1993. This paper summarizes the conclusions from the operational aspects of the study and reviews some early results from studies of the biological impacts. Harvesting costs to roadside were about $12 \%$ greater for the PC and GT and $49 \%$ greater for the SW. Cumulative losses to windthrow after three years were $25 \%$ in the GT and 5\% in the SW. Site disturbance, soil compaction and rates of organic matter decomposition were low across all harvested treatments. Rates of organic matter decomposition and $\mathrm{N}$ mineralization on SW, GT and PC were intermediate between CC and OG. Nutrient loss in soil solution was reduced with partial harvesting but lack of available nitrogen is limiting the early growth of coniferous regeneration among all systems. During spring and summer, SW and CC treatments were generally cooler than PC or GT. Damage to understory vegetation and advanced conifer regeneration was least in the $\mathrm{SW}$, which also provided the greatest amounts of seedfall among all harvested treatments.

Key words: Abies amabilis, Tsuga heterophylla, Thuja plicata, Chamaecyparis nootkatensis, harvesting costs, site impacts, silvicultural systems, shelterwood
Le partenariat du Montane Alternative Silvicultural Systems (MASS) a été constitué en 1992 afin d'évaluer de nouvelles approches en matière de récolte des vieilles forêts de haute altitude de l'île de Vancouver en Colombie-Britannique. Des coupes progressives uniformes (SW), des coupes de rétention d'arbres verts (GT) et des coupes jardinage par bouquets d'arbres (PC) ont été mises à l'essai en tant qu'alternatives à la coupe à blanc (CC). Tous les modes furent comparés à un témoin issu d'une vieille forêt (OG). La récolte se termina en 1993. Cet exposé résume les conclusions tirées des aspects opérationnels de l'étude et révise certains des résultats préliminaires provenant des études d'impacts biologiques. Les coûts de récolte au chemin étaient près de $12 \%$ supérieurs pour les PC et les GT et $49 \%$ plus élevés pour les SW. Les pertes cumulatives par suite de renversement au cours de trois ans étaient de $25 \%$ dans les GT et de $5 \%$ dans les SW. La perturbation de la station, la compaction du sol et les taux de décomposition de la matière organique étaient faibles pour tous les traitements de récolte. Les taux de décomposition de la matière organique et de minéralisation de l'azote sur les SW, GT et PC se situaient entre les $\mathrm{CC}$ et les OG. La perte d'éléments nutritifs disponibles dans le sol a été réduite dans la coupe partielle mais le manque d'azote accessible limite la croissance initiale de la régénération résineuse pour tous les modes. Au cours du printemps et de l'été, les sites des traitements SW et CC étaient plus frais que les sites de PC et de GT. Les dégâts occasionnés à la végétation sous-jacente ainsi qu'à la régénération résineuse préexistante étaient moins importants pour les SW, traitement qui ont également permis d'obtenir les plus fortes quantités de semences parmi tous les traitements.

Mots clés: Abies amabilis, Tsuga heterophylla, Thuja plicata, Chamaecyparis nootkatensis, coûts de récolte, impacts sur la station, modes sylvicoles, coupe progressive

\section{Background}

As forest companies in coastal British Columbia harvest more of their timber from higher elevations, it becomes crucial that the local effects of various silvicultural options are clearly understood. The predominantly old-growth montane to subalpine forests over $700 \mathrm{~m}$ elevation represent about $30 \%$ of the land base on Vancouver Island, and contain a significant part of the coastal timber harvest (Beese 1995a). Concerns that regeneration of natural and planted trees may not be meeting current growth expectations, and pressure to limit clearcutting in public forests, prompted the establishment of a research partnership to address these issues.

Irregular stocking density and growth stagnation in some large montane clearcuts suggest that regeneration may not be meeting current growth expectations. The apparent growth problems may be related to environmental conditions on large clearcuts that create unfavorable microclimate, vegetation competition,

\footnotetext{
${ }^{1}$ Natural Resources Canada, Canadian Forest Service, 506 W. Burnside Rd., Victoria, British Columbia, Canada V8Z 1M5.

${ }^{2}$ Sustainable Forestry Division, MacMillan Bloedel Limited, 65 Front St., Nanaimo, British Columbia, Canada V9R 5H9.
}

nutrition or other ecosystem processes affecting forest regeneration (Koppenaal and Mitchell 1992). Local and global demand to sustain a multitude of values from forest land, such as visual aesthetics and biological diversity, has raised other concerns with clearcutting. Coastal forest managers need to know where alternatives to clearcutting are feasible, economical and ecologically sound.

The Montane Alternative Silviculture Systems (MASS) partnership, a multi-disciplinary, multi-agency cooperative, was formed in 1992 to test new approaches to harvesting and regeneration in montane forests. MacMillan Bloedel Limited (MB), the Canadian Forest Service (CFS), and the Forest Engineering Research Institute of Canada (FERIC) cooperated in the project with participation by the University of Victoria (UVic), the University of British Columbia (UBC) and the British Columbia Ministry of Forests (BCMF). This paper describes the establishment of the project, summarizes findings on harvesting and costs, and reviews some early results from selected research studies that examine biological impacts. A description of MASS is given on the World Wide Web site at http://www.pfc.cfs.nrcan.gc.ca/www_users/galbraith/mass/mass.html. This site provides updates on individual studies and current publications listings. 
Table 1. Pre- and post-harvest forest characteristics for the Green Tree and Shelterwood treatments

\begin{tabular}{|c|c|c|c|c|}
\hline & \multicolumn{2}{|c|}{ Green Tree } & \multicolumn{2}{|c|}{ Shelterwood } \\
\hline & Pre & Post & Pre & Post \\
\hline \multicolumn{5}{|l|}{ Species composition (\% by basal area) } \\
\hline - Western hemlock & 44 & 51 & 43 & 49 \\
\hline - Amabilis fir & 23 & 16 & 29 & 33 \\
\hline - Western redcedar & 28 & 28 & 24 & 17 \\
\hline - Yellow-cedar & 5 & 5 & 4 & 1 \\
\hline Gross merchantable volume $\left(\mathrm{m}^{3} \mathrm{ha}^{-1}\right)$ & 1038 & 47 & 975 & 172 \\
\hline Percent of gross volume retained & & 5 & & 18 \\
\hline Net merchantable volume $\left(\mathrm{m}^{3} \mathrm{ha}^{-1}\right)$ & 723 & $\mathrm{n} / \mathrm{a}$ & 553 & 148 \\
\hline Basal area $\left(\mathrm{m}^{2} \mathrm{ha}^{-1}\right)$ & 86 & 4 & 73 & 18 \\
\hline Percent basal area retained & & 5 & & 25 \\
\hline Stems per hectare (over $17.5 \mathrm{~cm} \mathrm{DBH})$ & 599 & 22 & 494 & 206 \\
\hline Average stand height $(\mathrm{m})$ & 25 & 23 & 28 & 18 \\
\hline Average diameter (cm at $1.3 \mathrm{~m})$ & 41 & 40 & 45 & 32 \\
\hline $\begin{array}{l}\text { Understory trees } \\
\qquad(\mathrm{sph}>1.3 \mathrm{~m} \text { tall, }<17.5 \mathrm{~cm} \mathrm{DBH})\end{array}$ & 560 & $\mathrm{n} / \mathrm{a}$ & 569 & 300 \\
\hline Seedlings (<1.3 m tall, \% cover) & 28 & $\mathrm{n} / \mathrm{a}$ & 31 & 19 \\
\hline Snags ha-1 & 78 & 0 & 80 & 0 \\
\hline
\end{tabular}

\section{Objectives}

The overall objectives of the MASS project are to:

1. Test alternative silvicultural systems for $\mathrm{BC}$ coastal montane forests.

2. Document the operational costs and feasibility.

3. Study the biological and silvicultural impacts.

\section{Methods}

\section{Study Area}

The project is located at Lat. $49^{\circ} 55^{\prime} \mathrm{N}$; Long. $125^{\circ} 25^{\prime} \mathrm{E}$ on MacMillan Bloedel's private land south of Campbell River on Vancouver Island's east coast. It lies within the Montane Moist Maritime Coastal Western Hemlock biogeoclimatic variant (CWHmm2) which is characterized by cool temperatures, $\left(5.4^{\circ} \mathrm{C}\right.$ annual mean), a short growing season ( 150 frost free days), moderate rainfall (1892 $\left.\mathrm{mm} \mathrm{yr}^{-1}\right)$ and five months with snow (maximum snow depth $130 \mathrm{~cm}$ ) (Green and Klinka 1994). The site has a northerly aspect, a gentle slope of less than $20 \%$ and ranges in elevation from 740 to 850 metres. The stand is an old-growth forest dominated by amabilis fir (Abies amabilis Dougl. Ex. Forbes) and western hemlock (Tsuga heterophylla (Raf.) Sarg.), with varying amounts of western redcedar (Thuja plicata Donn ex. D. Don) and yellow-cedar (Chamaecyparis nootkatensis (D. Don) Spach) (Table 1). Overstory trees range in age from 200 to 800 years. Tree ages, stand structure and the presence of charcoal at the mineral soil surface, 10 to $40 \mathrm{~cm}$ under the forest floor, suggest that the stand developed in the absence of fire disturbance or large-scale windthrow for at least 500 years.

Understory vegetation on the study area is dominated by Alaskan blueberry (Vaccinium alaskaense), oval-leaved blueberry ( $V$. ovalifolium) and mosses (Rhytidiadelphus loreus, Hylocomium splendens and Rhytidiopsis robusta). Herbaceous cover occurs mostly on moist to wet microsites and consists of foamflower (Tiarella trifoliata), rosy twisted stalk (Streptopus roseus), several ferns and occasional skunk cabbage (Lysichiton americanum). Soils are predominantly Orthic and Gleyed Ferro-Humic Podzols over one metre deep, with some shallow areas over sandstone, shale or conglomerate bedrock. Well-drained to moderately well-drained soils occur on the middle to upper slopes and hummocks with moderately well-drained to imperfectly drained soils occurring on lower slopes and in depressions. Although the forest floor varies widely over short distances, a typical Mor humus form includes a thin $(0.5$ to $1.5 \mathrm{~cm})$ litter layer, a 3 to $5 \mathrm{~cm}$ matted "F" layer, and a well decomposed " $\mathrm{H}$ " layer 5 to $15 \mathrm{~cm}$ thick. Decomposed wood is a predominant component of deeper humus layers (Beese 1995b).

Forest cover and site associations were mapped at 1:5000 scale before harvesting. Pre-harvest above- and below-ground microclimate, physical and chemical soil properties (Senyk and Craigdallie 1995; Phillips 1995a), vegetation cover (Beese et al. 1995) and breeding bird communities (Bryant 1995) were also characterized at the same time.

\section{Silvicultural Systems}

The project studies four harvesting treatments, or silvicultural systems, and compares them to an unharvested old-growth control. The systems represent a gradient of microclimatic conditions and residual forest cover for regeneration protection and wildlife habitat. Each was designed with specific objectives in mind.

\section{Clearcut (CC)}

A 69-ha area, harvested over a two-year period from 1992 to 1993 , provides an example of past clear-cutting practices for comparison with the alternative systems. The regeneration objective is to establish a mixed stand of conifers through natural regeneration from advanced stocking and seed-in, supplemented by fill-planting to achieve stocking targets (1200 stems ha- $\left.{ }^{-1}\right)$ and desired species composition.

\section{Patch Cut (PC)}

Small cutblocks were designed with alternating leave strips so that regeneration is within two tree lengths of an edge. This provides the cutover areas with seed-fall and protects regeneration against snow, wind and temperature extremes. Trees were cut in three 1.5 to 2.0 ha patches (about $120 \times 125 \mathrm{~m}$ ) within each treatment block. Except for size, the concept is similar to a strip shelterwood. The remaining $50 \%$ of the stand will be harvested after regeneration reaches $10 \mathrm{~m}$ in height. This also spreads harvesting throughout a longer time period for aesthetic and wildlife habitat values. Regeneration will be achieved primarily through natural stocking, supplemented by planting as required.

\section{Green Tree Retention (GT)}

Also known as clearcutting with reserves, the objective is to leave 25 trees ha-1 in small clearcuts to enhance structural diversity of future stands for wildlife and aesthetics. It is similar to a seed tree silvicultural system except that the reserves will be left for the entire rotation to meet other objectives. Trees were selected for relatively even distribution, windfirmness, safety and representation of the entire stand profile. Five snags ha ${ }^{-1}$ will be created in future for cavity nesting birds. Natural regeneration is prescribed, supplemented by planting as required to achieve a mixed species composition.

\section{Shelterwood (SW)}

This system provides protection for regeneration against snow, wind and temperature extremes, and enhances the structural diversity of future stands for wildlife and aesthetic values. Trees representing the entire stand profile and 30 percent of the basal area 


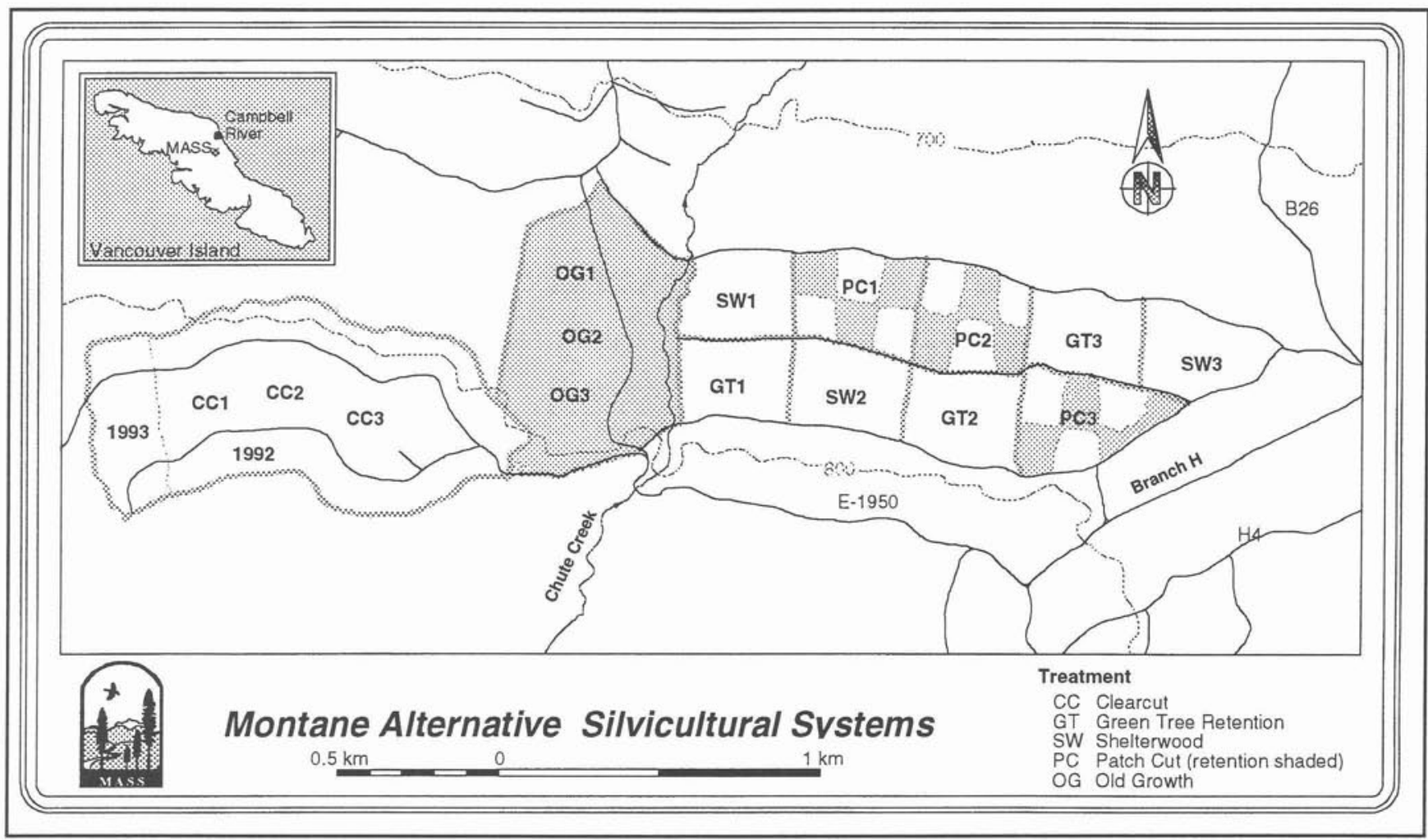

Fig. 1. Study area location and experimental layout.

(approximately $200 \mathrm{stems} \mathrm{ha}^{-1}>17.5 \mathrm{~cm} \mathrm{DBH}$ ) were left throughout the stand. Reserve trees were selected for yarding feasibility, safety, wind-firmness and residual stand structure. Although the approach is considered a uniform shelterwood, clumped distribution was necessary to facilitate harvesting and protect the smaller trees. If feasible and economical, a portion of the leave trees will be recovered when regeneration is established, leaving up to 25 wildlife trees ha- ${ }^{-1}$. A second option identified in the stand prescription is to leave all residual trees for the entire rotation, creating a multi-aged "irregular" shelterwood. Regeneration will be achieved primarily through advanced natural stocking and seed-in supplemented by planting as required.

\section{Experimental Design}

The experiment includes three replicate blocks for each of the three alternative systems to clearcutting. These blocks are mostly rectangular, average 9 ha in size and occupy a total area of 94 ha. The 94 ha alternative treatment area is buffered to the north and south by old-growth which provides some measure of wind protection for the foreseeable future. Adjacent to these is a 69 ha Clearcut treatment and a 20 ha Old Growth baseline monitoring reserve (Fig. 1). An aerial view of the alternative silvicultural systems is shown in Fig. 2.

Most research is being conducted within a 1.0 to 1.6 ha "core" located in the centre of each 9 ha treatment replicate, buffered by three tree heights of the same treatment. Three replicate "cores" were also established within each of the Old Growth and Clearcut areas. All studies are referenced to a $60 \mathrm{~m}$ sampling grid that was established before harvesting using permanent metal markers.

\section{Harvesting}

The Worker's Compensation Board of British Columbia was involved during harvest planning to ensure safety requirements were met. Trees were marked to meet the specific silvicultural objectives established for each treatment. Several days of training occurred, with field input on marking from equipment operators, fallers, researchers and other operational personnel. Where a marked tree could not be retained, fallers could choose an alternative tree of similar size. Trees were bucked to specified log lengths at the stump to maximize recovery.

Field layout of road systems and treatment blocks was completed in 1992. Leave trees were marked before harvest in the Green Tree and Shelterwood treatments. Trees were felled manually in all treatments, beginning in May 1993. A hydraulic log loader (backhoe) was used to forward the logs from stump to roadside, lifting or swinging the logs to avoid damage to standing timber. Hoe-forwarding has been the method of choice for yarding timber on this type of terrain. In the Shelterwood, trees were felled and yarded from 15 - to 20 -m wide access corridors before felling the remaining trees throughout the treatment blocks. Logs in the corridors were ground-skidded to roadside with a flexible-tracked (KMC) skidder. All yarding was completed by November 1993. Costs for falling and forwarding were calculated using the standard methods of the Forest Engineering Research Institute of Canada (Phillips 1996). Full details on falling and forwarding methodology can be found in Phillips (1995a; 1996).

\section{Results and Discussion Harvesting}

The combined costs of felling and yarding were $12 \%$ higher for the Patch Cut and Green Tree treatments and $49 \%$ higher for the Shelterwood (Table 2). Incremental costs were considered to be all expenses above conventional clearcutting. Felling costs were greater for the Patch Cut and Shelterwood than the 


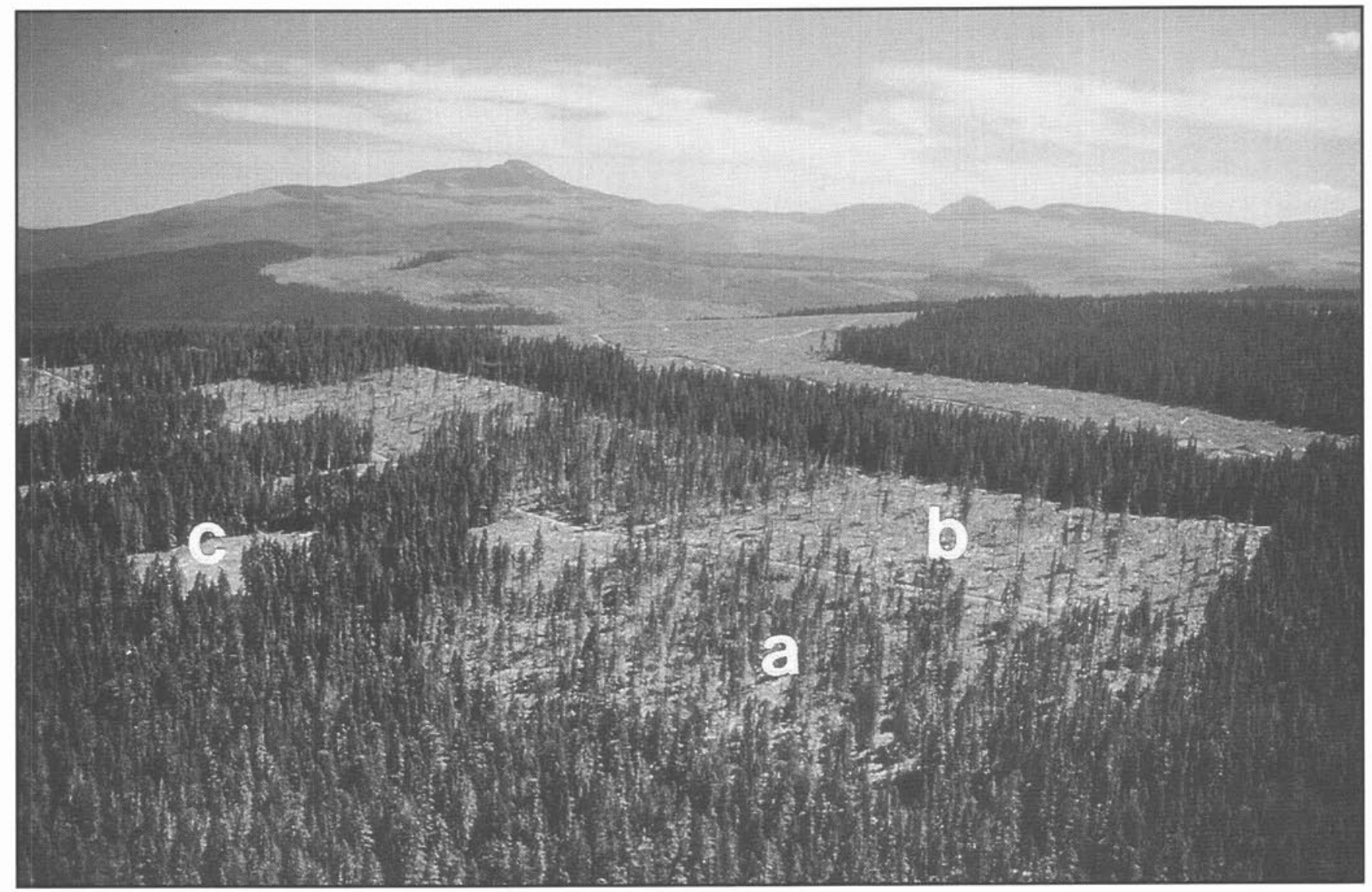

Fig. 2. An oblique aerial view of the alternative silvicultural systems two years after harvesting; a) Shelterwood (SW1), b) Green Tree (GT1) and c) Patch Cut (PC1).

Table 2. Percent increase in cost per cubic metre harvested over Clearcut base cost

\begin{tabular}{lccc}
\hline Treatment & Felling & Yarding & Total $^{1}$ \\
\hline Green Tree & -2 & 21 & 12 \\
Patch Cut & 14 & 4 & 12 \\
Shelterwood & 17 & 62 & 49 \\
\hline
\end{tabular}

${ }^{1}$ Costs to roadside, including extra tree-marking and layout (Beese 1995a).

Green Tree or Clearcut. Forwarding costs were greatest in the Shelterwood, followed by the Green Tree. Forwarding costs were similar for the Patch Cut and Clearcut areas. Another economic consideration associated with the Patch Cuts was road development cost in relation to timber harvested. As $50 \%$ of the trees were not harvested, initial road development costs had to be absorbed by only half of the volume accessed.

In all treatments, breakage during felling was a problem and was not included in the analyses of costs (Phillips and Beese 1996). Many of the larger trees had a pronounced lean which pre-determined the direction of felling and led to more breakage. To avoid breakage to trees already felled in the Shelterwood corridors, trees were forwarded several times as felling progressed. Felling trees into the confined space of the small Patch Cuts was more difficult and time consuming, particularly in the corners. Although felling in the Green Tree was no more costly than the Clearcut, having to avoid leave trees led to greater stem breakage. In future, it may not be necessary to pre-mark the leave trees as fallers could easily be trained to make appropriate selections. Future applications of the Green Tree might consider grouping the leave trees in clumps, rather than uniform distribution. This would improve forwarding efficiency as the equipment operator would be able to swing felled trees more easily.

The Shelterwood treatment presented the greatest challenge to both felling and forwarding because of the high numbers of leave trees. Because the basal area targets and leave-tree criteria make the Shelterwood treatment complex, pre-marking trees prior to felling is highly recommended rather than having trees selected by fallers. The greatest damage to residual trees in the Shelterwood occurred along the boundaries of the yarding corridors where logs scarred the base of trees. These badly-scarred residuals were left as a protective "buffer" and were removed when the forwarder made its final pass.

Much of the trial success was due to good project planning and coordination, with the crews willing to try new applications of existing skills (Phillips 1996). They accepted the rationale of the project objectives and found solutions to operational challenges. The research team communicated with the crew throughout the study and answered questions as they arose.

\section{Windthrow}

Alternative silvicultural systems will only be successful if the residual stands remain wind-firm over the long term. Windthrown trees have been tallied annually by canopy class and species within the Green Tree and Shelterwood treatments as well as along the boundaries of the Patch Cut and Clearcut 


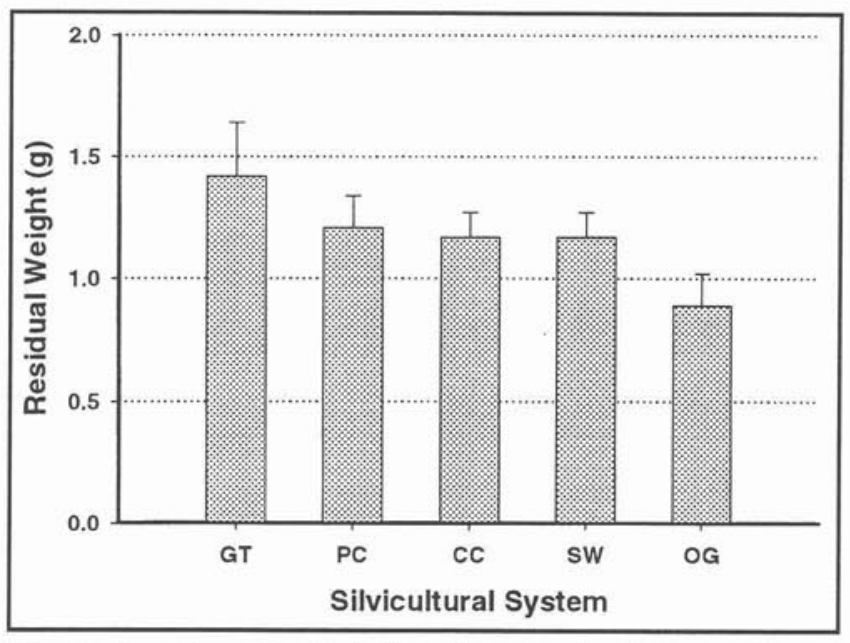

Fig. 3. Organic matter depletion of western hemlock needles residual weight (g) after two years (from Prescott 1997). Error bars represent standard deviations of the means.

blocks. After three seasons (i.e. by June 1996), the Green Tree treatment lost $25 \%$ of the leave-trees to windthrow ( $6 \mathrm{sph})$, and the Shelterwood lost $5 \%(11 \mathrm{sph})$. The Patch Cut and Clearcut treatments lost the equivalent of 4.3 and $5.8 \mathrm{sph}$, respectively. The greatest windthrow losses were in the intermediate crown class. Western redcedar appeared to be more windfirm than either amabilis fir or western hemlock. Most of the windthrow occurred from late fall through early spring from storms blowing from the southeast or northwest.

Windthrow decreased for the first three seasons after harvesting, particularly in the Shelterwood where $84 \%$ of the windthrow occurred in the first year and windthrow in the third year was negligible. In the adjacent Old Growth, only two recent windfalls were observed in the entire 20 ha area. At the start of the fourth season, a 25-year storm on October 17, 1996 blew down 325 trees. Winds were from the southeast and remained strong from 9 a.m. to $5 \mathrm{p} . \mathrm{m}$., reaching nearly $9 \mathrm{~m} \mathrm{sec}^{-1}(32 \mathrm{~km}$ $\mathrm{h}^{-1}$ ) at $3 \mathrm{~m}$ height in the Clearcut (speeds would be much greater at the top of the tree canopy (Oke 1978)). This storm doubled the cumulative windthrow in the Shelterwood and increased windthrow in the Green Tree blocks by $36 \%$. There was no significant windthrow on the edges of the Patch Cuts and Clearcut from the October 17 th storm. These early losses to windthrow are not surprising when one considers that more than $70 \%$ of the basal area of the original stand was removed in these treatments, pre-disposing them to a high degree of windthrow risk (Stathers et al. 1994). Windthrow losses over the three-year period at MASS were similar to those found in a silvicultural systems study of second-growth (90-120 year-old) Douglasfir (Pseudotsuga menziesii (Mirb.) Franco) at Roberts Creek near Sechelt, BC (D'Anjou 1997). However, they are much greater than those found in the Date Creek study near Hazelton, BC of mature (140 year), mixed species, high latitude $\left(55^{\circ} 22^{\prime} \mathrm{N}\right)$ forest where windthrow losses over a two-year period were less than $2 \%$ (Coates 1997).

\section{Site Impacts}

\section{Soil Compaction}

The primary cause of site disturbance was from the forwarders moving logs to roadside, with the tracks of this heavy equipment compacting or displacing the forest floor or mineral

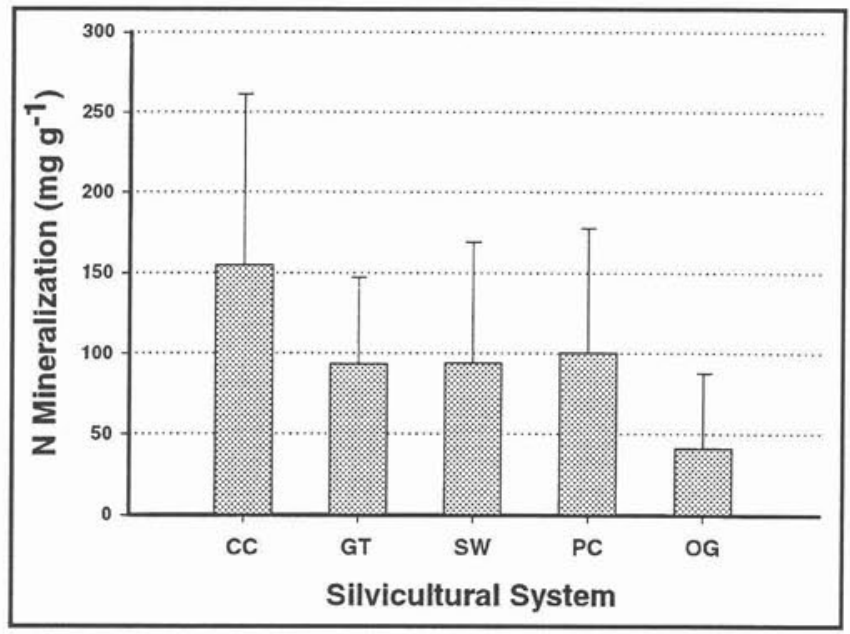

Fig. 4. $\mathrm{N}$ mineralization $\left(\mathrm{mg} \mathrm{g}^{-1}\right)$ of forest floor material after 2 months in the field. (from Prescott 1997). Error bars represent standard deviations of the means.

soil. Generally, dispersed site disturbance after harvesting was similar among all harvested treatments. Only $10 \%$ of the areas were compacted by the forwarder and of these, half had a compacted zone less than $10 \mathrm{~cm}$ in depth (Phillips 1996). Deep humus layers and abundant slash probably protected the mineral soil from severe disturbance and dispersed the weight of the harvesting equipment. Although the soil density on the tracks $\left(1.18 \mathrm{~g} \mathrm{~cm}^{-3}\right)$ was considered to be below the threshold for impeding root growth (Heilman 1981; Lousier 1990), second-year height growth of western hemlock seedlings, planted as bioassays on these tracks, was at least $15 \%$ less than seedlings planted on adjacent uncompacted areas (Senyk 1996).

The forwarding corridors in the Shelterwood were highly compacted, with mineral soil bulk densities up to $50 \%$ greater than undisturbed areas (Senyk and Craigdallie 1995). These corridors were rehabilitated using a small backhoe (Cat 225) at a cost of $\$ 0.85 \mathrm{~m}^{-1}$ of trail (Phillips 1995b). The backhoe loosened compacted soil, removed buried woody debris, placed logs along slope contours to divert water flows, and re-established water courses.

\section{Climate}

Spring and summer soil surface temperature maxima were approximately $20^{\circ} \mathrm{C}$ greater in the Clearcut than in the Old Growth (Dunsworth and Arnott 1995). During this period, average mean air temperatures $(1.3 \mathrm{~m})$ indicated that Clearcut and Shelterwood treatments were slightly cooler (by $0.4^{\circ} \mathrm{C}$ ) than Patch Cut or Green Tree, but for different reasons. Cooler temperatures in the Clearcut were likely due to more wind associated with a longer fetch and, in the Shelterwood, to a shading effect from the remaining overstory (Dunsworth and Arnott 1996). Both Green Tree and Patch Cuts were protected by trees in adjacent treatments or leavestrips, which may have trapped heat and increased the daily temperature averages.

\section{Litter Decomposition and Nutrients}

Understanding how the interconnected processes of litter decomposition, nitrogen mineralization, and nutrient losses through leaching may be influenced by levels of canopy retention during harvest is an important consideration for long-term 


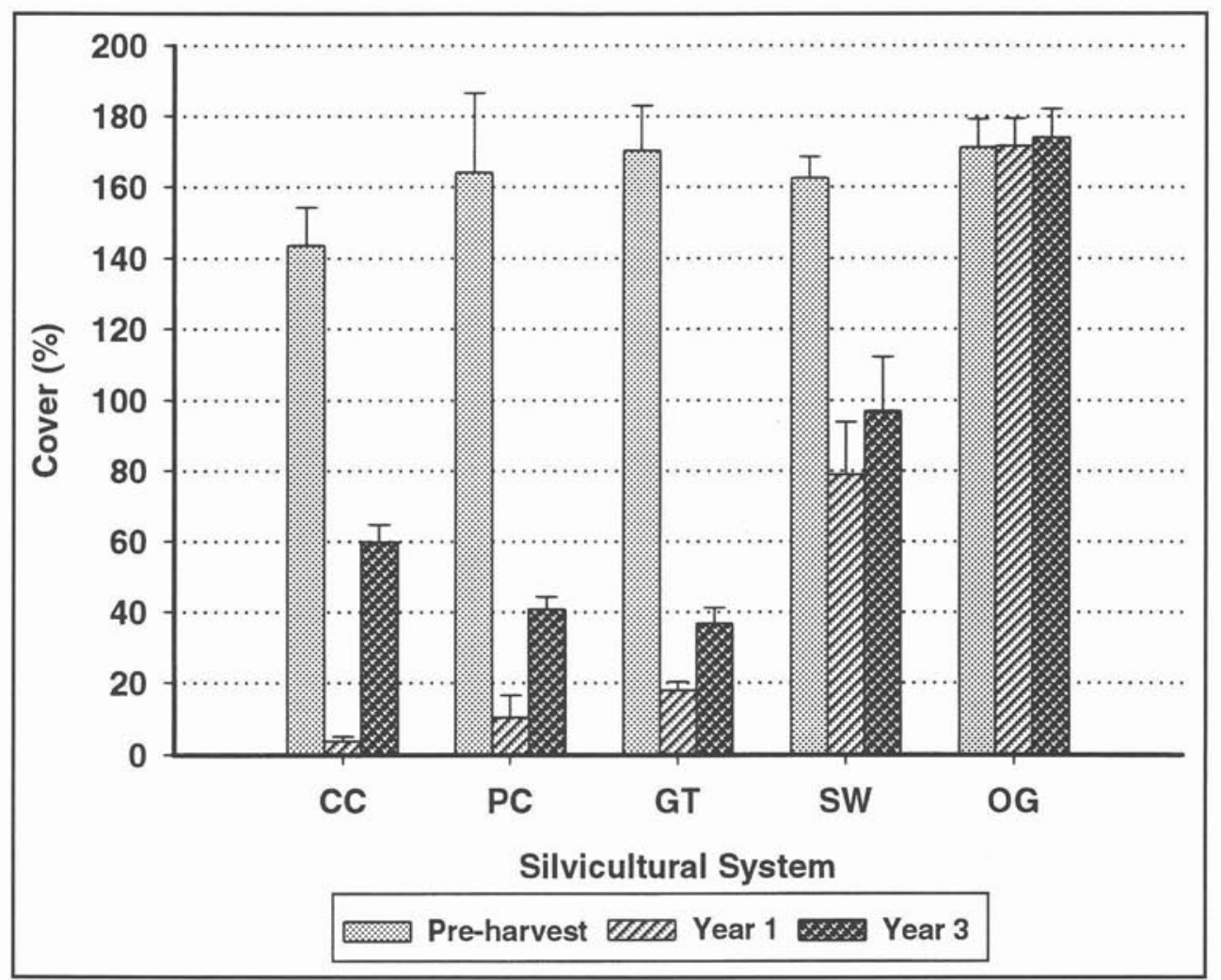

Fig. 5. Percent cover of understory vegetation pre-harvest (0), and post-harvest (Year 1 and 3). Note that cover exceeds $100 \%$ due to overlapping strata. Error bars represent standard errors of the means.

sustainability of management on montane forest sites. Rates of organic matter decomposition and nitrogen mineralization are being quantified at MASS using in-situ incubation techniques near climate stations in each harvest treatment (Prescott 1995). Litter bags made of fiberglass screening $(10 \times 10 \mathrm{~cm})$ were filled with $2 \mathrm{~g}$ of three different substrates: western hemlock needles, lodgepole pine (Pinus contorta Dougl. Ex. Loud.) needles or forest floor $(\mathrm{FH})$ material. Litter bags were pinned to the surface and $\mathrm{FH}$ bags were buried in the forest floor.

During the first two years after harvesting, weight loss of needle litter was fastest in the Old Growth, possibly due to higher moisture in the surface layers during the summer (Fig. 3) (Prescott 1997). Forest floor material lost about $10 \%$ of its initial weight over two years in all silvicultural systems. Assuming a linear rate of decay, some of the original forest floor material should remain on the site for 20 years, by which time a new organic layer should develop. Depletion of organic matter is unlikely to be a concern on this site.

Leaching of $\mathrm{N}$ from soils following clearcutting has been attributed to accelerated decomposition and nutrient mineralization of the residual organic matter (Prescott 1995). This is usually attributed to greater microbial activity resulting from the warmer, moister conditions in the clearcuts. In situ rates of net $\mathrm{N}$ mineralization at MASS were greatest in the Clearcut and least in the Old Growth (Fig. 4) (Prescott 1997). Concentrations of nitrate were greater in the Clearcut than in the other silvicultural systems or the Old Growth. The results indicate that partial cutting affects $\mathrm{N}$ mineralization less than clearcutting, and that the increase in $\mathrm{N}$ mineralization and nitrification after clearcutting was not the result of faster decomposition of

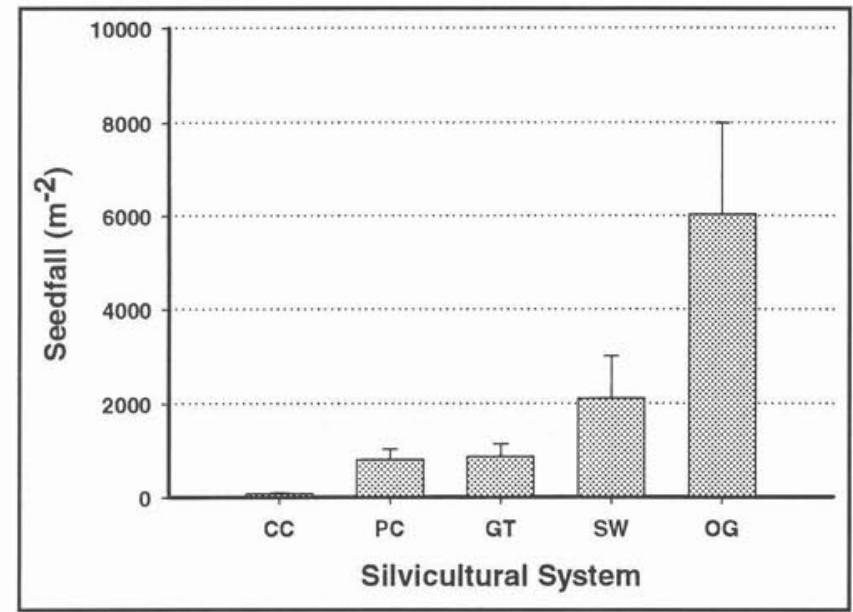

Fig. 6. Total seedfall (no. $\mathrm{m}^{-2}$ ) from Nov. 1993 through Oct. 1996. Error bars represent standard errors of the means.

the organic matter. High rates of $\mathrm{N}$ mineralization and leaching in the Clearcut may be related more to changes in carbon supply (lack of litter input) than any alterations to the microclimate.

Nutrient losses from the rooting zone were measured by collecting soil solutions in lysimeters placed at various soil depths along a gradient of canopy opening and forest floor condition. Early results indicate that nutrient loss in soil solution in montane forests can be reduced by partial cutting as seen in the Green Tree and Shelterwood treatments when compared to the Clearcut (Feller and Olanski 1995). 
A)

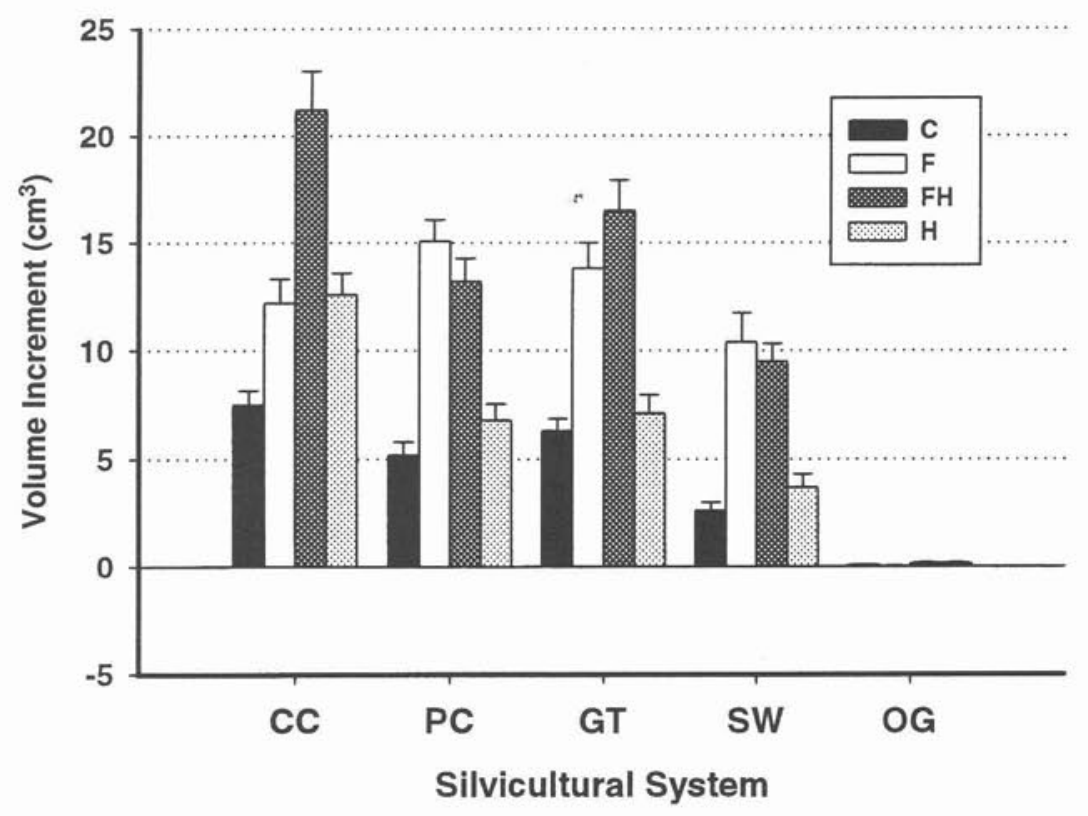

B)

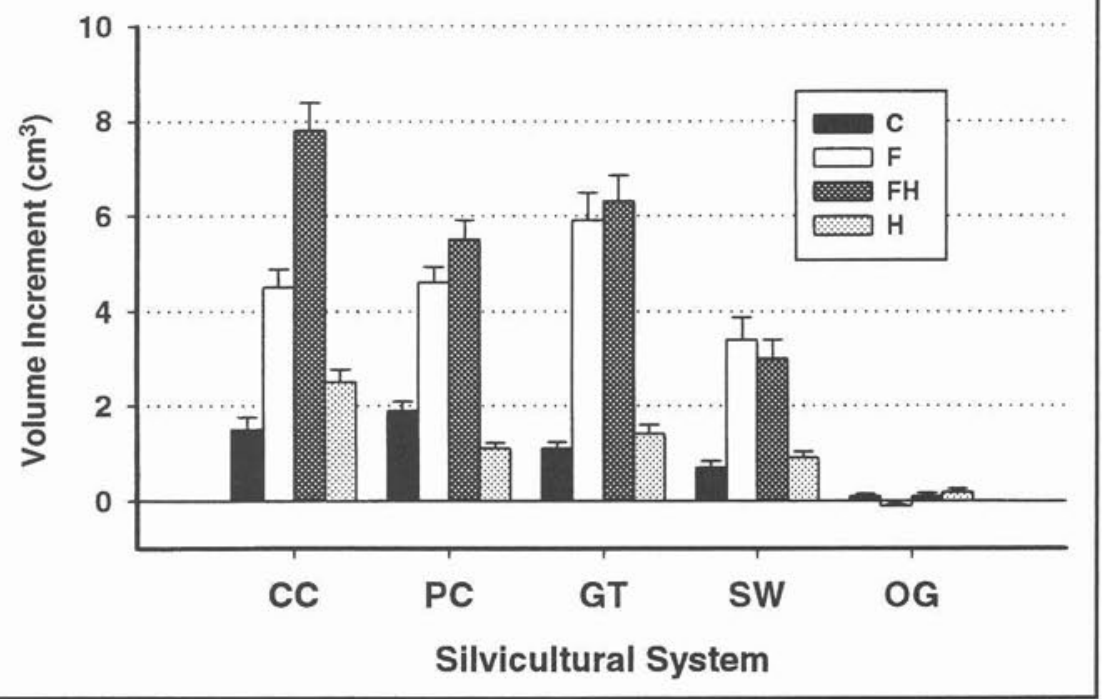

Fig. 7. Western hemlock (A) and amabilis fir (B) stem volume increment in the second growing season after planting in each of the four post-planting treatments $(\mathrm{C}=$ Control, $\mathrm{F}=$ Fertilizer, $\mathrm{H}=$ Herbicide, and $\mathrm{FH}=$ Fertilizer and Herbicide combined) (from Dunsworth and Arnott 1996). Error bars represent standard errors of the means.

\section{Understory Vegetation and Seedfall}

The cover, frequency and number of species of understory plants decreased after all harvesting treatments. The Shelterwood retained the greatest cover of understory trees, shrubs and mosses compared to the other systems where understory vegetation was protected from damage by forwarding within the undisturbed clumps of leave trees (Fig. 5). The shade provided by the Shelterwood has allowed mosses to survive at over half of their original cover of $71 \%$, in contrast to the three more open treatments where mosses were reduced to $10 \%$ cover or less. By the third growing season, cover increased in the harvested areas primarily due to herbaceous colonizers such as fireweed 
(Epilobium angustifolium). The Old Growth showed only minor variations in species cover and frequency over the same period.

Seed-fall traps were sampled annually in May, August and November. There was significantly more seedfall in the first season (1993/94) than in the following two years. First season seedfall of 4,900 seeds $\mathrm{m}^{-2}$ was among some of the highest reported values (Beese et al. 1995). Unlike previous seasons, the greatest amount of seed in the third season (1995/96) and in fall of 1996 was collected in the Shelterwood, not the Old Growth treatment. This suggests that the harvesting stimulated seed production (i.e. a stress crop). Seedfall from all years combined, however, showed there was significantly more seedfall in the Old Growth than in any of the harvested areas (Fig. 6). Hemlock seeds were much more abundant than the other species on all treatments. The Old Growth and all partially cut areas had the greatest proportion of the species with heavier seed (amabilis fir and yellow-cedar). Low numbers of seed of all species reached the centre of the 69 ha clearcut.

\section{Regeneration}

Among many regeneration studies in progress at MASS, one is using planted amabilis fir and western hemlock as a bioassay to evaluate how the environments created by the different silvicultural systems affect foliar physiology and biomass growth. This experiment assumes that the silvicultural systems provide a wide range of light, temperature, evaporative demand and moisture. Furthermore, it assumes that nutrition will be affected by both the microclimate conditions within each silvicultural system through changes in decomposition rate, nutrient availability and nutrient use from other vegetation. These assumptions are being tested by a factorial experiment within each silvicultural system that compares vegetation removal (with glyphosate herbicide), fertilization (with slow-release Nutricote), a combination of these two treatments, and a control treatment with no intervention (Dunsworth and Arnott 1995).

During the first two growing seasons, there were very small differences in seedling growth of both planted species among the harvested treatments (Dunsworth and Arnott 1996). However, the fertilized seedlings had significantly greater $(p<0.01)$ height and diameter growth (Fig. 7) indicating that lack of nitrogen is limiting the initial growth of regeneration in this ecosystem. Shortage of nitrogen may be associated with high accumulations of organic matter and low levels of organic decomposition (Hinckley et al. 1981). Response to added N was much greater than the seedling's growth response to reduced vegetative competition. However, there were some increases in growth in the herbicide plots in the Clearcut where herb and shrub invasion was greatest among all of the silvicultural systems (Fig. 7). Greater invasion in the Clearcut may be partially because it was harvested one year before the other treatments.

There were few, if any differences in foliar photosynthesis or chlorophyll fluorescence in the planted seedlings among all treatments and there were no seasonal soil water deficits among the silvicultural systems (Mitchell and Arnott 1996). These are very early results which, in all probability, will change through time. More definitive information will be obtained when a subsample of the planted seedlings will be excavated in 1997 to assess above- and below-ground biomass accumulation. Early results, however, indicate that lack of available nitrogen is more limiting to growth of coniferous regeneration than any microclimates created by the various levels of canopy removal.

\section{Summary and Conclusions}

Shelterwood, Green Tree and Patch Cut systems can be implemented successfully in old-growth forests under the conditions tested at the MASS site. Over the short-term, many lessons have been learned about the feasibility and cost implications of alternative harvesting systems for montane forests. In summary, we found that:

- harvesting costs were about $12 \%$ greater for the Patch Cut and Green Tree and $49 \%$ greater for the Shelterwood compared to the Clearcut base cost;

- crew involvement in the planning and layout, and close onsite supervision was essential;

- when residual trees were left in clumps in the Shelterwood, productivity was maintained with minimal damage to stems; and

- cumulative losses to windthrow after three years have been relatively high in the Green Tree and Shelterwood systems. The project has created a research installation where longterm, multi-disciplinary projects are coordinated. From 17 active projects, a few were selected for this paper that focus on the biological impacts. Results to date show that:

- site disturbance and soil compaction resulting from groundbased forwarding systems were relatively minor;

- during spring and summer, Shelterwood and large Clearcut treatments were generally cooler than the Patch Cuts or Green Tree retention in small clearcuts;

- decomposition of surface organic matter was fastest in the Old Growth, but rates of decomposition were slow (approx. $5 \%$ annually) among all treatments;

- rates of $\mathrm{N}$ mineralization on the partial cutting treatments were intermediate between the Clearcut (highest) and Old Growth (lowest);

- nutrient loss in soil solution was reduced by partial cutting, and in the small Patch Cuts;

- lack of available N, caused by high accumulations of organic matter and slow decomposition rates, is limiting the early growth of coniferous regeneration;

- damage to understory vegetation and natural regeneration was least in the Shelterwood, which also had the greatest seedfall among all harvested treatments.

We stress that the above are very early results from long-term investigations. Many of the studies will be monitored for at least 20 years to provide more definitive answers on the implications of alternative silvicultural systems in montane ecosystems of coastal British Columbia.

\section{Acknowledgments}

The MASS project was sponsored by MacMillan Bloedel Limited, the Canadian Forest Service, the Forest Engineering Research Institute of Canada and Industry Canada. Funding was provided by the Canada-BC Forest Resource Development Agreement (FRDA II), Forest Renewal BC and the sponsoring agencies. The authors wish to thank all colleagues within the MASS project who kindly gave permission to use their results in this review article.

\section{References}

Beese, W.J. 1995a. Clearcut alternatives in Coastal montane forests. Can. For. Indust. (Sept.); p. 28-31.

Beese, W.J. 1995b. Montane Alternative Silviculture Systems(MASS): Introduction and objectives. In Proc. Montane Alternative Silviculture Systems (MASS) workshop. J.T. Arnott, W.J. Beese, A.K. Mitchell 
and J. Peterson (eds.). June 7-8, 1995, Courtenay, BC, Can. For Serv. and BC Min. For., Victoria, BC FRDA Rep. 238: 3-8.

Beese, W.J., J. Sandford and J. Toms. 1995. Montane Alternative Silvicultural Systems (MASS) forest structure and natural vegetation dynamics. In Proc. Montane Alternative Silviculture Systems (MASS) workshop. J.T. Arnott, W.J. Beese, A.K. Mitchell and J. Peterson (eds.). June 7-8, 1995, Courtenay, BC, Can. For Serv. and BC Min. For., Victoria, BC FRDA Rep. 238: 113-122.

Bryant, A.A. 1995. Putting MASS in context: Bird communities in Vancouver Island old-growth forests. In Proc. Montane Alternative Silviculture Systems (MASS) workshop. J.T. Arnott, W.J. Beese, A.K. Mitchell and J. Peterson (eds.). June 7-8, 1995, Courtenay, BC, Can. For Serv. and BC Min. For., Victoria, BC FRDA Rep. 238: 101-112. Coates, K.D. 1997. Windthrow damage 2 years after partial cutting at the Date Creek silvicultural systems study in the Interior Cedar-Hemlock forests of northwestern British Columbia. Can. J. For. Res. 27: 1695-1701.

D'Anjou, B. 1997. Roberts Creek demonstration shelterwood block 1993-1996. In Proc. Coastal Silviculture Committee 1997 Summer Workshop, June 17-18, 1997, Sechelt, BC. 8 p.

Dunsworth, B.G. and J.T. Arnott. 1995. Growth limitations of regenerating montane conifers in field environments. In Proc. Montane Alternative Silviculture Systems (MASS) workshop. J.T. Arnott, W.J. Beese, A.K. Mitchell and J. Peterson (eds.). June 7-8, 1995, Courtenay, BC, Can. For Serv. and BC Min. For., Victoria, BC FRDA Rep. 238: 48-68.

Dunsworth, B.G. and J.T. Arnott. 1996. Growth limitations of regenerating montane conifers in field environments. Unpublished Progress Rep. $(72 / 31 \mathrm{~F})$ prepared for Science Council of British Columbia by MacMillan Bloedel Ltd. and Pac. For. Cent., Can. For. Serv., Victoria, BC. 28 p.

Feller, M.C. and P. Olanski. 1995. Influence of alternative timber harvesting regimes in montane coastal western hemlock zone forests on soil nutrient leaching: Initial results. In Proc. Montane Alternative Silviculture Systems (MASS) workshop. J.T. Arnott, W.J. Beese, A.K. Mitchell and J. Peterson (eds.). June 7-8, 1995, Courtenay, BC, Can. For Serv. and BC Min. For., Victoria, BC FRDA Rep. 238: 89-100.

Green, R.N. and K. Klinka. 1994. A field guide for site identification and interpretation for the Vancouver Forest Region. BC Min. For., Land Manage. Handbook No. 28., 285 p.

Heilman, P. 1981. Root penetration of Douglas-fir seedlings into compacted soil. For. Sci. 27: 660-666.

Hinckley, T.M., R.O. Teskey, R.H. Waring and Y. Morikawa. 1981. The water relations in true firs. In Proc. Biology and Management of True Fir in the Pacific Northwest Symposium. C.D. Oliver and R.M. Kenady (eds.). Univ. Wash., Inst. For. Resources, Contrib. No. 45: 85-93. Koppenaal, R.S. and A.K. Mitchell. 1992. Regeneration of montane forests in the coastal western hemlock zone of British Columbia: A literature review. Pac. For. Cent., Can. For. Serv., Victoria, BC, FRDA Rep. 192. 22 p.
Lousier, D.J. 1990. Impacts of forest harvesting and regeneration on forest sites. BC Min. For., Victoria, BC Land Manage. Rep. No. 67., $92 \mathrm{p}$.

Oke, T.R. 1978. Boundary layer climates. Methuen, London and New York. 372 p.

Mitchell, A.K. and J.T. Arnott 1996. Indicators of growth limitations of regenerating montane conifers under alternative silvicultural systems. Unpublished Progress Rep. (72/31E) prepared for Pac. For. Cent., Can. For. Serv., Victoria, BC 8 p.

Phillips, E. 1995a. Harvesting logistics and costs. In Proc. Montane Alternative Silviculture Systems (MASS) workshop. J.T. Arnott, W.J. Beese, A.K. Mitchell and J. Peterson (eds.). June 7-8, 1995, Courtenay, BC, Can. For Serv. and BC Min. For., Victoria, BC FRDA Rep. 238: 9-13.

Phillips, E. 1995b. Site rehabilitation with a Caterpillar 225: Shortterm assessment. For. Eng. Res. Inst. Can., Vancouver, BC Field Note No.: Silviculture-80, 2 p.

Phillips, E.J. 1996. Comparing silvicultural systems in a coastal montane forest: Productivity and cost of harvesting operations. Can. For. Serv. and BC Min. For., Victoria, BC, FRDA Rep. 247. 42 p.

Phillips, E. and W.J. Beese 1996. Comparing silvicultural systems in a British Columbia montane forest: What have we learned so far? Abstr. In Proceedings CWF/IUFRO Joint Conference, Montreal, Que., Sept. 9-11, 1996.

Prescott, C.E. 1995. Rates of organic matter decomposition and nitrogen mineralization in forest floors at MASS. In Proc. Montane Alternative Silviculture Systems (MASS) workshop. J.T. Arnott, W.J. Beese, A.K. Mitchell and J. Peterson (eds.). June 7-8, 1995, Courtenay, BC, Can. For Serv. and BC Min. For., Victoria, BC FRDA Rep. 238: 81-88.

Prescott, C.E. 1997. Effects of clearcutting and alternative silvicultural systems on rates of decomposition and nitrogen mineralization in a coastal montane forest. For. Ecol. and Manage. 95: 253-260.

Senyk, J.P. 1996. Effects of harvesting and site rehabilitation practices on soil and forest productivity in Montane Alternative Silviculture Systems (MASS). Unpublished Progress Rep. (72/31G) prepared for Pac. For. Cent., Can. For. Serv., Victoria, BC. 9 p.

Senyk, J. and D. Craigdallie. 1995. Effects of harvesting and trail rehabilitation on soil and long-term forest productivity in alternate silviculture systems trials. In Proc. Montane Altemative Silviculture Systems (MASS) workshop. J.T. Amott, W.J. Beese, A.K. Mitchell and J. Peterson (eds.). June 7-8, 1995, Courtenay, BC, Can. For Serv. and BC Min. For., Victoria, BC FRDA Rep. 238: 25-36

Stathers, R.J., T.P. Rollerson and S.J. Mitchell. 1994. Windthrow handbook for British Columbia forests. BC Min. For., Victoria, BC Working Paper 9401, $31 \mathrm{p}$. 